УДК 336.1: 368

JEL: G22, E44

Соболсва-Терещенко Олена Анатоліївна

кандидат економічних наук, доцент кафедри фінансів та економіки,

Київський університет імені Бориса Грінченка,

Київ, Україна

ORCID ID: 0000-0002-1086-1192

e-mail:t8000@i.ua

Броніцька Катерина Сергіївна

здобувач ступеня магістр,

кафедри фінансів та економіки,

Київський університет імені Бориса Грінченка,

Київ, Україна

e-mail:insurancekbron@gmail.com

\title{
ФІНАНСОВА СТРАТЕГІЯ СТРАХОВОЇ КОМПАНІЇ В УМОВАХ ВПРОВАДЖЕННЯ ЗАКОНОДАВЧИХ ЗМІН РЕГУЛЮВАННЯ УЧАСНИКІВ ФІНАНСОВОГО РИНКУ
}

Анотація. В рамках статті досліджуються зміст і основні проблеми формування, реалізації та управління фінансовою стратегією страхової компанії, фінансового стратегічного планування. Позначається місце фінансової стратегії в загальній системі фінансового планування та прогнозування. Розроблено етапи впровадження фінансових стратегій страховими компаніями на основі існуючих розробок для інших суб'єктів господарювання, розкрито сутність та послідовність здійснення кожного 3 етапів застосування страховою компанією фінансової стратегії. Проведено аналіз адекватності розроблених етапів фінансової стратегії страхових компаній існуючим екзогенним та ендогенним факторам та обгрунтовано застосування саме розроблених стратегічних етапів. Проведено аналіз законодавчих змін стосовно регулювання діяльності учасників небанківського фінансового ринку та встановлені вірогідні результати вказаних змін. Встановлено позитивні та негативні наслідки запровадження змін законодавства стосовно «СПЛІТУ». Виявлено зміну факторів, які впливають на процес здійснення суб'єктами небанківського фінансового ринку своєї діяльності та здійснено її аналіз на основі існуючих статистичних даних. На основі аналізу літературних джерел та існуючого досвіду діяльності страхових компаній досліджено вплив запровадження Закону про «СПЛІТ» на фінансову стратегію страхової компанії. Дається оцінка перспектив та ефективності впровадження заходів щодо змін умов регулювання страхових компаній як учасників небанківського фінансового ринку. Проаналізовано зміну чинників, що впливають на провадження страховою компанією фінансової стратегії у зв’язку 3 запровадженням закону про «СПЛІТ» та здійснено передбачення майбутньої результативності здійснення страховими компаніями своєї фінансової стратегії в умовах практичного запровадження Закону про "СПЛІТ".

Ключові слова: фінансова стратегія; СПЛІТ; небанківський фінансовий ринок; регулятор, страхова компанія.

DOI: http://doi.org/10.32750/2019-0207

\section{ВСТУП}

Постановка проблеми. Зв'язок трансформаційних процесів які відбуваються 3 вітчизняними страховиками та фінансами $є$ загальновідомим фактом. Успішність діяльності страхових сьогодення повністю залежить від ефективності здійснення ними пошуків оптимальних джерел фінансування, влучності інвестиційних рішень, аналізу грошових потоків, розробки податкової та облікової політик, умов державного регулювання їх діяльності. Саме тому важливо здійснити дослідження етапів впровадження Закону про «СПЛІТ» у процесі створення ним правової основи щодо зміни умов регулювання учасників небанківського фінансового ринку. Дане внесення змін до 
законодавства має на меті переш за все припинення дублювання функцій національних регуляторів у сфері фінансових ринків, спрощення та прозорість ухвалення управлінських рішень в цій сфері, а також поліпшення умови ведення бізнесу 3 одночасним посиленням відповідальності суб'єктів фінансового ринку. Запровадження Закону щодо вдосконалення функцій державного регулювання ринків фінансових послуг («СПЛІТ»), потребує більш грунтовного дослідження сутності фінансової стратегії страхових компаній, факторів що на неї впливають, що обумовлює важливість та актуальність даної теми дослідження.

Аналіз останніх досліджень і публікацій. Дослідження страхової справи в Україні, організація управління страховими компаніями знайшло відображення в працях М.М. Александрової [1], О.І. Барановського [2], М.П. Ніколенка [2], С.С. Осадця [3], О.Ф. Філонюка [2], В.М. Фурмана [2] та ін.

Проблеми розробки та застосування фінансової стратегії підприємств розглядались у роботах багатьох вітчизняних і закордонних вчених, у тому числі А.М. Поддерьогіна [4], І.А. Бланка [5], С.Н. Станіславчик [6], С.В. Лукіної [7], Л.В. Дикань [8] та ін.

Аналіз праць науковців дозволяє зробити висновок про недостатній рівень теоретичної розробки питання управління страховою компанією з урахуванням змін в державному регулюванні розвитку фінансового ринку країни та важливість подальших досліджень в цій галузі.

Мета статті дослідження сутності та розробка етапів фінансової стратегії страховика, предикація впливу на неї запровадження Закону про «СПЛІТ».

\section{РЕЗУЛЬТАТИ ДОСЛІДЖЕННЯ}

Виклад основного матеріалу дослідження. На ринкові перетворення економіки будь-якої країни впливає сукупність факторів, які $є$ причиною невизначеності характеристик майбутнього стану екзо- та ендогенного середовищ кожного окремого суб'єкта економічної діяльності. Умови функціонування цих суб'єктів на ринку, їх діяльність обумовлена розвитком ринкових відносин. Саме тому суб'єктам економічної діяльності усіх форм власності та господарювання задля забезпечення перспектив власного існування на фінансовому ринку варто здійснювати свою діяльність на основі стратегічного управління, важливою складовою якого $є$ процес формування та реалізації фінансової стратегії. Потреба прискіпливого аналізу існуючих проблем та розробка практичних рішень у сфері забезпеченні стійкого розвитку суб'єкта економічної діяльності у сучасних умовах, сутнісна природа головних економічних категорій фінансів, грошей та кредиту обумовлюють важливість розробки фінансової стратегії страхових компаній.

Фінансові стратегії провідних страхових груп охоплюють широкий спектр діяльності (страхування, управління активами, банківська справа) і спрямовані переважно на захоплення вигідних стратегічних фінансових позицій. У стратегічному фінансовому управлінні провідні страхові компанії враховують коливання валютних курсів, використовують офшорні компанії, запроваджують інформаційну відкритість.

Разом з цим, особливий спосіб розвитку ринкових відносин, специфічність українського ринку не дозволяють перекласти зарубіжні приклади використання фінансових стратегій провідних страхових груп без певних модифікацій, додаткового вивчення та перевірки на практиці існуючих теоретичних засад впровадження вказаних стратегій.

За останні роки різним аспектам проблеми стратегічного менеджменту присвячено багато праць зарубіжних та вітчизняних економістів, в яких достатньо детально розглядається методологія формування та реалізації фінансової стратегії суб'єкта 
економічної діяльності, чим підкреслюється актуальність даної проблеми. Страховим компаніям сьогодення задля продовження свого існування вкрай необхідно вчасно й відповідно до ситуації надавати зворотній зв'язок зовнішнім чинникам ринкового середовища, що впливають на їх діяльність як безпосередньо, так і опосередковано. В цьому плані вони залежні від фінансових криз, змін у податковому законодавстві, нестабільності політичної ситуації в країні, зміни тарифів, різкого коливання курсу валют та інших факторів.

Досягнення високого рівня конкурентоспроможності, платоспроможності, рентабельності та фінансової стабільності страхової компанії можливе лише за умови професійного залучення у його діяльність фінансової політики, яка, у свою чергу, має на меті як здійснення вірних управлінських рішень щодо використання фінансових ресурсів, контролю над оборотними коштами та інвестиціями, досягнення бажаного рівня прибутковості. Існуючий взаємозв'язок вказаних складових i $€$ своєрідним продуцентом фінансової стратегії як основи управління страхової компанії у цілому.

Необхідність розробки фінансової стратегії страхової компанії обумовлена також фактом того, що джерелом формування інших видів ресурсів (наприклад, інвестиційні ресурси, матеріальні, трудові, тощо) виступають саме фінансові ресурси.

На даний час більшість страхових компаній розуміють необхідність свідомого та перспективного управління фінансовою діяльністю на основі наукової методології передбачення iї форм і напрямів, адаптації до загальних цілей розвитку та змінних умов зовнішнього фінансового середовища через запровадження Закону про «СПЛІТ» (рис.1.).

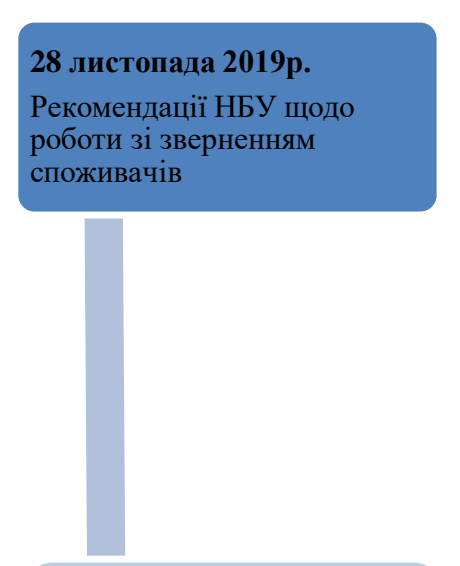

Грудень 2019р.

Вимоги НБУ до договорів (набувають чинності через 3 місяці)

Вимоги НБУ до візуального сприйняття реклами(набувають чинності 02.06.2020)

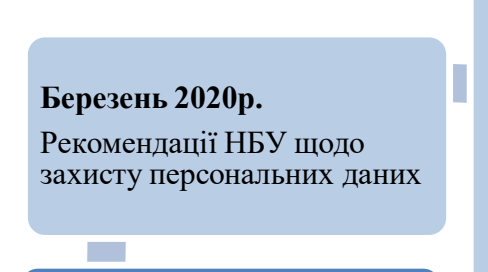

Червень 2020p. Вимоги НБУ до інформації на сайтах та у рекламі про мікрокредити

Рекомендації НБУ щодо захисту маломобільних груп Вимоги НБУ до розкриття інформації через дистанційні електронні канали обслуговування Вимоги НБУ до роботи банків зі зверненнями громадян

02 березня 2020p.
Вимоги НБУ до розкриття інформації на сайтах

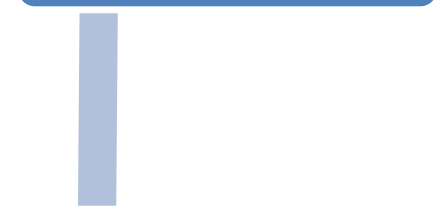

\section{8 січня 2020p.}

Закон про захист прав споживачів

Вимоги НБУ до розрахунку процентної ставки за споживчими кредитами

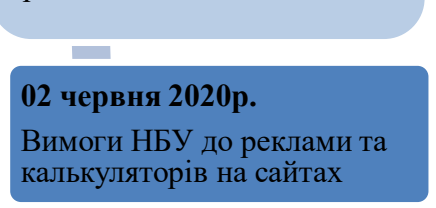

Вересень 2020p.

Вимоги НБУ до уникнення нечесних практик

Нормативно-правові акти у процесі розробки, очікують ухвалення

Ухвалені нормативно-правові акти, очікують набуття чинності

Рис. 1. Етапи запровадження Закону про «СПЛІТ» 
Слід зазначити. Що метою Закону $є$ скорочення кількості регуляторних $\mathrm{i}$ контролюючих органів на ринках небанківських фінансових послуг за рахунок розподілу функцій Національної комісії, що здійснює державне регулювання у сфері ринків фінансових послуг між Національним банком України (НБУ) та Національною комісією 3 цінних паперів та фондового ринку (НКЦПФР).

Зокрема, згідно з Законом НБУ стане регулятором страхових, лізингових, фінансових компаній, кредитних спілок, ломбардів та бюро кредитних історій, а НКЦПФР регулюватиме недержавні пенсійні фонди та фонди фінансування будівництва.

Також, Закон передбачає перехідний період, упродовж якого відбуватиметься передача функцій від Національної комісії з регулювання ринків фінансових послуг до НБУ та НКЦПФР. Триватиме він до 01 липня 2020 року. Тобто до 30 червня включно регулюванням ринку, як і раніше займатиметься Нацкомфінпослуг, а 31 липня наступного року функції Нацкомфінпослуг почнуть виконувати НБУ та НКЦПФР.

Фінансова стратегія виступає ефективним інструментом перспективного управління фінансової діяльності страхової компанії, що підпорядкований (в умовах значних змін системи державного регулювання ринкових процесів, макроекономічних показників, кон'юнктури фінансового ринку і виникаючою в результаті невизначеністю) реалізації цілей його загального розвитку.

Через зрозумілу актуальність на сучасному етапі розвитку економіки дослідження проблеми формування фінансової стратегії страхової компанії як складової загальної його стратегії, все більше вчених приділяють даному напрямку увагу у своїх роботах. Саме такий підхід пов'язаний 3 тим, що звуження фінансової діяльності страхової компанії лише до оперативного управляння окремими складовими фінансових ресурсів вже не є достатнім.

Детальний аналіз хронології та змісту наукових публікацій, присвячених проблемі розробки фінансової стратегії вказує, що формування фінансової стратегії страхової компанії кореспондує з тенденціями макроекономічних показників в економічному секторі України.

Виходячи 3 цього, можна зробити висновок, що фінансова стратегія страхової компанії - це визначення довгострокових фінансових цілей та завдань, що включають в себе формування, управління та планування його фінансових ресурсів 3 метою підвищення вартості страхової компанії за умови забезпечення іiї фінансової рівноваги.

На сучасному етапі розробка страховими компаніями фінансової стратегії базується в першу чергу на методологічних засадах такої концепції як «стратегічне управління», що досить активно впроваджується у діяльність корпорацій країн Західної Європи а також США. Вказана концепція стратегічного управління має на меті чітке стратегічне позиціонування суб'єктів економічної діяльності ( не виключаючи також їх фінансову позицію), яке представлене системою цілей та принципів їх функціонування, механізмів взаємодії елементів організаційної та господарської структури, а також способах їх адаптації до змін умов екзогенного середовища.

Методологія стратегічного планування складає сутнісну основу стратегічного управління. Звичне довгострокове планування засноване на концепції екстраполяції існуючих тенденцій до розвитку. Разом з цим, стратегічне планування враховує не лише вказані тенденції, а й поєднання небезпек та можливостей розвитку суб'єкта економічної діяльності, припустимість виникнення не врахованих евентуальних ситуацій, що можуть вплинути на сформовані тенденції у майбутніх планових періодах.

Існуючі підходи з позиції різних авторів щодо визначення категорії «фінансова стратегія» є актуальними для окремих напрямків дослідження. Так, за Поддєрьогіним 
фінансова стратегія - це формування системи довгострокових цілей фінансової діяльності і вибір найефективніших способів їх досягнення. Фінансова стратегія $\epsilon$ частиною загальної стратегії [4, с. 35]. Даний підхід є найбільш поширеним та приближеним до дійсності у сучасних умовах, фінансова стратегія визначаються незамінною частиною загальної стратегії, а не просто окремим видом діяльності, яку можна проводити, а можна і не проводити.

3 одного боку, фінансова стратегія - визначення основних довгострокових фінансових цілей та завдань й утримання курсу дій, розподілу ресурсів, необхідних для досягнення цих цілей [5, с.15]. 3 іншого боку, фінансова стратегія - стратегія, метою якої $\epsilon$ підвищення багатства власника [7, с.113].

У дослідженнях Станіславчік зазначено, що головним при проведенні фінансової стратегії є підвищення вартості [6, с.47]. На думку Лукіної, основною передумовою та причиною розробки та впровадження фінансової стратегії $є$ підвищення багатства власника. Ключовим поняттям у визначенні фінансової стратегії Дикань $є$ управління фінансовими ресурсами підприємства, без вказання бажаного результату від впровадження вказаної стратегії: Фінансова стратегія підприємства - стратегія, що спрямована на управління його фінансовими ресурсами [8, с.13].

Кожен з запропонованих вченими у своїх доробках підходів до визначення поняття «фінансова стратегія» $\epsilon$ актуальним для певного окремого випадку. Розглядаючи результати впровадження фінансової стратегії варто спиратись на визначення Станіславчіка та Лукіної, у яких фокус зміщено на результати. При розробці фінансової стратегії спираючись на неї, як на частину загальної стратегії варто звертатись до підходу Поддєрьогіна. Найбільш загальним підходом до визначення фінансової стратегії є підхід Дикань, тому що у ньому ключовим поняттям $\epsilon$ управління фінансовими ресурсами в цілому.

Враховуючи умови сучасного етапу розвитку страхового ринку країни (наприклад, такі як підвищення рівня конкуренції у порівнянні з минулими роками) головним завданням, яке постало перед українськими страховими компаніями є забезпечення ними свого стабільного розвитку та стійкого функціонування. Важливою умовою забезпечення компанією тенденції до стабільного розвитку є беззаперечно застосування у своїх діяльності способів та методів фінансових стратегій. Нестабільність ринкової ситуації наразі топ-менеджмент компаній вже не може дозволити собі реагувати лише на явища, що відбуваються на даний час. Постає питання необхідності реагування на зміни майбутнього. Тобто, їх передбачення та вироблення способу керування ними до моменту їх виникнення. За умов мінливості змін та страховому ринку та виникаючої $з$ ними невизначеності варто застосовувати у своій діяльності такий інструмент як стратегія. Структура та осяг фінансових ресурсів страхової компанії являє собою один із найвагоміших чинників забезпечення її стабільного розвитку.

Важливим для сталого розвитку страхової компанії, як і для інших суб'єктів економічної діяльності, є чинний етап розвитку економіки території, де страхова компанія провадить свою діяльність та країни в цілому, політичний стан, розвиненість місцевого та загального страхового ринку, розвиненість застосовуваних технологій, рівень довіри споживачами послуг до фінансових інститутів, стан власних можливостей страхової компанії та їі регіональних підрозділів, рівень ії страхової культури. Оскільки сутність такої категорії як стратегія пов'язана 3 поняттям «стабільність», варто розглянути що таке стабільність для страхової компанії. Для фінансово-кредитних установ, в тому числі і страхових компаній, $є$ актуальним питання стабільності у процесі залучення споживачів надаваних послуг і стабільність займаної ринкової позиції. 
Найважливішими чинниками страхової компанії виступають ії фінансовий стан та показник стійкості. Завдяки встановленню нормативів страховим компаніям вдається попередити неплатоспроможність.

Головна мета фінансової діяльності страхової компанії - зростання показника добробуту та підвищення його вартості на ринку. Цьому значною мірою сприяє зменшення кількості точок дотику бізнесу та держави, що передбачається 3 впровадженням Закону. Для досягнення цієї мети важливу роль матиме зменшення регулюючих та контролюючих органів.

Успішність впровадження фінансової стратегії страховою компанією в першу чергу залежить від першого етапу іiі застосування страховиком, тобто - розробки, вона гарантована у випадку адекватності визначення стратегічних цілей через призму реальних фінансових можливостей, за умови абсолютно чіткої централізації фінансового управління, гнучкості та відповідності методів його здійснення мінливості фінансовоекономічних характеристик розвитку страховика.

Не у останню чергу процес формування фінансової стратегії страховою компанією залежить від змін екзогенного середовища, що у свою чергу за умови застосування даної стратегії викликає потребу у постійному вивченні проблеми фінансової стратегії та іiї взаємозв'язку із тактичними діями страхової компанії.

Завдяки дослідженню періодичних видань стосовно процесу впровадження фінансової стратегії страховими компаніями вдалось виявити, що існує суперечливість поглядів щодо послідовності, наповнення за змістом та кількості етапів ії формування. Серед найбільш дискусійних питань фінансової стратегії страхових компаній варто виділити розробку початкового та кінцевого етапів.

Спираючись на проведене дослідження стосовно послідовних етапів впровадження фінансових стратегій, виділимо їх відповідні етапи (рис.1.).

РОзРОБКА
ФІНАНСОВОї
СТРАТЕГІї
•визначення мети ФС
•визначення періоду
реалізації ФС
•збір інформації про
зовнішне та внутрішне
середовище
• обгрунтування власного
фінансового потенціалу
•вибір ФС на підставі
оцінювання показника
конкурентоспроможності
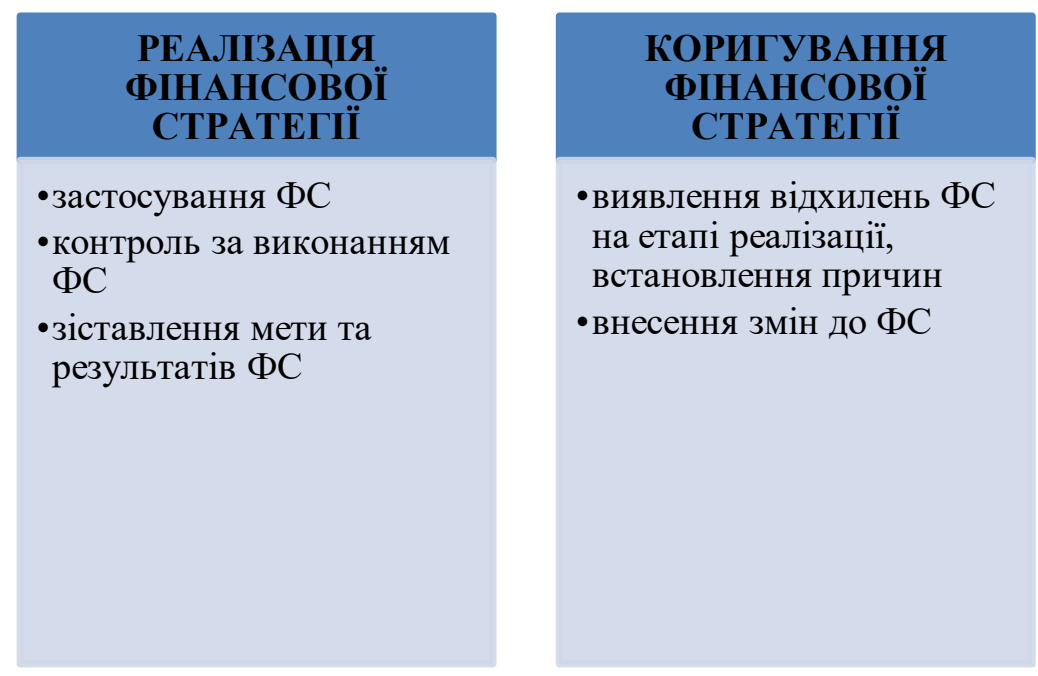

Рис. 1. Етапи формування фінансової стратегії страховика (розробка авторів)

Кожен із етапів впровадження фінансової стратегії є рівнозначним за важливістю до іншого. По-перше, прискіпливий та обгрунтований процес розробки фінансової стратегії надзвичайно спростить процес іiі реалізації страховою компанією. По-друге, адекватна реалізація розробленої фінансової стратегії є запорукою іiі успішності в цілому. Ефективно реалізована фінансова стратегія є запорукою пошуків шляхів 
вдосконалення фінансової діяльності підприємства. По-третє, оперативне (в силу ендогенних факторів, які можуть виникнути у процесі застосування) чи пост коригування фінансової стратегії допоможе покращити фінансові результати страховика як від iii реалізації, так і від реалізації загальної стратегії підприємства. Застосовані фінансові рішення стосовно корекції фінансової стратегії забезпечать суб'єкту господарювання стабільний розвиток на довготерміновий строк.

Існування такого явища екзогенного середовища страхових компаній як корупція $\epsilon$ одним із найголовніших чинників впливу на процес застосування компанією фінансової стратегії. Вплив корупційних явищ варто брати до уваги як у процесі розробки фінансової стратегії, так і у процесі іiі застосування та корекції. Корекція застосовуваної фінансової стратегії страховою компанією має відбуватися не лише після етапу іiі безпосереднього здійснення (як пост корекцію), а і на двох перших етапах впровадження - формування та безпосередньо застосування.

Згідно з підсумками 2018 року Україна за цим показником зайняла 120 сходинку у переліку зі 180 країн світу. Найвищий бал у рейтингу мають держави, в яких корупцію вважають мінімальною; найнижчий - найбільш корумповані, за сприйняттям, країни. Так, Данія в останньому рейтингу набрала 88 балів зі ста можливих і посіла перше місце (вважається найменш корумпованою за сприйняттям країною), Нова Зеландія - 87 балів, Фінляндія, Сінгапур та Швеція - по 85 балів. Менш корумпованими за сприйняттям, ніж Україна, є всі країни ЄС, включно з Болгарією, яка має найгірші показники в Свросоюзі -42 бали.

Із пострадянських держав Україну випередили всі країни Балтії, а також Грузія, Вірменія, Молдова і Білорусь. I хоча в Індексі сприйняття корупції (ICK), що укладається глобальною антикорупційною організацією Transparency International та опирається на оцінки підприємців і аналітиків, з часом позиції країни у рейтингу покращуються, ситуація є далекою від припустимої. Проблеми, які виникають при такому рівні хабарництва та зловживання несуть в собі негативний вплив на досягнення цілей своєї загальної стратегії в цілому. Корупція є чи не одною з найбільших проблем вітчизняної економіки в цілому, зрозуміло, що іiі існування вплине на процес застосування фінансової стратегії страховиками, що здійснюють свою діяльність на українському ринку.

Таблиия 1

Індекс сприйняття корупції (Corruption Perceptions Index, CPI)

\begin{tabular}{|l|l|c|c|c|c|}
\hline \multicolumn{1}{c|}{ Країна } & \multicolumn{4}{c|}{ Регіон } & \multicolumn{4}{c|}{ Кількість балів } \\
\cline { 3 - 7 } & & 2018 & 2017 & 2016 & 2015 \\
\hline Данія & Західна Свропа та Свропейський Союз & 88 & 88 & 90 & 91 \\
\hline Нова Зеландія & Азіатсько-Тихоокеанський регіон & 87 & 89 & 90 & 91 \\
\hline Фінляндія & Західна Свропа та Свропейський Союз & 85 & 85 & 89 & 90 \\
\hline Ліберія & Африка на південь від Сахари & 32 & 31 & 37 & 37 \\
\hline Малаві & Африка на південь від Сахари & 32 & 31 & 31 & 31 \\
\hline Малі & Африка на південь від Сахари & 32 & 31 & 32 & 35 \\
\hline Україна & Східна Свропа та Центральна Азія & 32 & 30 & 29 & 27 \\
\hline Джибуті & Африка на південь від Сахари & 31 & 31 & 30 & 34 \\
\hline Габон & Африка на південь від Сахари & 31 & 32 & 35 & 34 \\
\hline
\end{tabular}

Завдяки прийняттю Закону «СПЛІТ» нагляд та регулювання ринку страхових, лізингових і факторингових компаній, кредитних спілок та інших фінансових компаній перейдуть від Нацкомфінпослуг до НБУ. Згадані зміни до законодавства дозволять 
знизити кількість та якість корупційних ризиків, що впливають на впровадження фінансових стратегій страховими компаніями завдяки зменшенню кількості регулюючих i контрольних органів, погоджувальних процедур та покращити умови здійснення страховиками своєї діяльності взагалі. Оскільки зазначені законодавчі зміни, згідно офіційних даних, мають прискорювати розвиток економіки в цілому, якість провадження страховими компаніями своєї основної діяльності також має оптимізуватись.

Оскільки завдяки прийняттю Закону « СПЛІТ» очікується зниження рівня корупції, варто очікувати спрощення процесу застосування фінансових стратегій страховим компаніями, адже згаданий фактор ризику мінімізується, поки що не варто говорити про повну декоруптизацію, втім навіть незначне ії зниження дозволить страховим компаніям ефективніше проводити діяльність стосовно стратегічного планування в цілому, в тому числі фінансове.

Отже, результатом дослідження є визначення поняття фінансової стратегії, аналіз підходів наукового співтовариства до цієї категорії, розроблені етапи впровадження фінансової стратегії саме страховими компаніями. Здійснено аналіз законодавчої бази стосовно законодавчих змін регулювання діяльності учасників небанківського фінансового ринку, до яких належать страхові компанії та їх вплив на процеси формування, застосування та корекції фінансової стратегії страховиками. Були визначені особливості змін факторів, що діють на впровадження фінансової стратегії страховими компаніями у призмі змін регуляторного процесу над їх діяльністю.

\section{ВИСНОВКИ ТА ПЕРСПЕКТИВИ ПОДАЛЬШИХ ДОСЛІДЖЕНЬ.}

Виходячи $з$ здійсненого дослідження, можна зробити висновок, що фінансова стратегія страхової компанії - це визначення іiі довгострокових фінансових цілей та завдань, що включають в себе формування, управління та планування його фінансових ресурсів 3 метою підвищення вартості страхової компанії за умови забезпечення фінансової рівноваги.

На сучасному етапі розробка фінансової стратегії базується в першу чергу на методологічних засадах такої концепції як «стратегічне управління», що досить активно впроваджується у діяльність корпорацій країн Західної Європи а також США. Вказана концепція стратегічного управління має на меті чітке стратегічне позиціонування суб'єкта економічної діяльності ( не виключаючи також їх фінансову позицію), яке представлене системою цілей та принципів їх функціонування, механізмах взаємодії елементів організаційної та господарської структури та також способах адаптації до здатних до змін умов екзогенного середовища.

Спираючись на проведене дослідження стосовно послідовних кроків впровадження фінансових стратегій страховими компаніями, пропонується виділити три блоки застосування фінансових стратегій:

1. Безпосередньо розробка фінансової стратегії страховою компанією 3 урахуванням факторів ендо- та екзогенного середовища ( таких як зміна законодавчої бази, загальноекономічні чинники, облікова та регуляторна політика держави стосовно суб'єкту господарювання), що впливають на провадження нею своєї діяльності, та у результаті на ефективність застосування страховиком фінансової стратегії.

2. Реалізація попередньо розробленої фінансової стратегії.

3. Коригування виявлених слабких складових фінансової стратегії, які не були враховані у процесі іiі розробки та ті, що виникли уже після іiї повного розроблення на етапі реалізації, у тому числі непередбачувані фактори екзогенного середовища. 
Фінансові стратегії страхових компаній, України, мають враховувати зміну державної фінансової політики. Впровадження запропонованих рекомендацій сприятиме узгодженню інтересів суб'єктів страхових відносин, підвищенню захисту прав споживачів фінансових послуг та позитивно впливатиме на забезпечення економічної безпеки держави.

Напрямом подальшого дослідження $є$ внесення пропозиції щодо покращення рейтингової оцінки стратегічного фінансового управління страховою компанісю, що враховує ринкові позиції компанії та коливання у вітчизняній страховій галузі, та надасть можливість знизити рівень інформаційної асиметрії на фінансовому ринку.

\section{СПИСОК ВИКОРИСТАНИХ ДЖЕРЕЛ}

1. Александрова, М. М. (2010). Теоретичні основи фінансової стратегії страхової компанії. Вісник Житомирського державного технологічного університету, 2(52), 217-220.

2. Фурман, В. М., Філонюк, О. Ф., Ніколенко М. П., Барановський, О. І. (2008). Стратегічне управління страховою компанією [монографія]. КНЕУ. KHEУ

3. Осадець, С. С., Мурашко, О. В., Фурман, В. М. (2011). Страховий менеджмент: підручник. Київ:

4. Білик, М. Д., Піддєрогін, А. М., Бабяк, Н. Д. (2017). Фінансовий менеджмент. Київ: КНЕУ.

5. Бланк, І. А. (2008). Фінансова стратегія підприємства. Київ: Ніка - Центр.

6. Станіславик, Ю. Н. (2008). Основи фінансового менеджменту. Миколаїв: Ось - 89.

7. Лукіна, Ю.В. (2008). Формування та реалізація стратегії управління фінансами підприємства. Фінанси України, 3, 113.

8. Дикань, Л. В. (2008). Стратегічне управління фінансовими ресурсами промислового підприємства. Фінанси України, 3, 12-18.

9. Гудзь, О. І. (2017). Формування фінансової стратегії підприємства. Науковий вісник Міжнародного гуманітарного університету, 24, 107- 110.

10. Гончаренко, О.М. (2015). Фінансова стратегія: теоретичні питання розробки та впровадження. Вісник соціально-економічних досліджень: зб. наук. праць, 56 (1), 35-40.

11. Tang, T. L. P., Sutarso, T., Ansari, M. A., Lim, V. K., Teo, T. S., Arias-Galicia, F., ... \& Vlerick, P. (2018). Monetary Intelligence and Behavioral Economics: The Enron Effect-Love of money, corporate ethical values, Corruption Perceptions Index (CPI), and dishonesty across 31 geopolitical entities. Journal of Business Ethics., 148(4), 919-937.

12. Бас Ю.В. (2016). Теоретичні основи формування фінансової стратегії підприємства. Наука й економіка, 1 (41), 73-77.

13. Костирко, Л. А., Середа, О. О. (2019). Фінансовий потенціал як об'єкт фінансового регулювання розвитку суб'єктів господарювання. Вісник соціально-економічних досліджень: зб. наук. праць, 69 (1), 149157.

14. Ramskyi, A., \& Budnichenko, I. (2018). Financial stability of a bank - factor of stability of banking system. European Scientific Journal of Economic and Financial Innovation, (2), 5-11. https://doi.org/10.32750/2018-0201 


\section{Соболева-Терещенко Елена Анатольевна}

кандидат экономических наук, доцент кафедры финансов и экономики,

Киевский университет имени Бориса Гринченко,

Киев, Украина

ORCID ID: 0000-0002-1086-1192

e-mail:t8000@i.ua

Броницкая Екатерина Сергеевна

соискатель степени магистр,

кафедры финансов и экономики,

Киевский университет имени Бориса Гринченко,

Киев, Украина

e-mail:insurancekbron@gmail.com

\section{ФИНАНСОВАЯ СТРАТЕГИЯ СТРАХОВОЙ КОМПАНИИ В УСЛОВИЯХ ВНЕДРЕНИЯ ЗАКОНОДАТЕЛЬНЫХ ИЗМЕНЕНИЙ О РЕГУЛИРОВАНИИ УЧАСТНИКОВ ФИНАНСОВОГО РЫНКА}

Аннотация. В рамках статьи исследуются содержание и основные проблемы формирования, реализации и управления финансовой стратегией страховой компании, финансового стратегического планирования. Обозначается место финансовой стратегии в общей системе финансового планирования и прогнозирования. Разработаны этапы внедрения финансовых стратегий страховыми компаниями на основе существующих разработок для других субъектов хозяйствования, раскрыта сущность и последовательность осуществления каждого из этапов применения страховой компанией финансовой стратегии. Проведен анализ адекватности разработанных этапов финансовой стратегии страховых компаний существующим экзогенным и эндогенным факторам и обосновано применение именно разработанных стратегических этапов. Проведено анализ законодательных изменений по регулированию деятельности участников небанковского финансового рынка и установлены достоверные результаты указанных изменений. Установлены положительные и отрицательные последствия внесения изменений законодательства в отношении «СПЛИТА». Выявлено изменение факторов, влияющих на процесс осуществления субъектами небанковского финансового рынка своей деятельности и осуществлено его анализ на основе существующих статистических данных. На основе анализа литературных источников и существующего опыта деятельности страховых компаний исследовано влияние введения Закона о «СПЛИТЕ» на финансовую стратегию страховой компании. Дается оценка перспектив и эффективности внедрения мероприятий по изменению условий регулирования страховых компаний как участников небанковского финансового рынка. Проанализировано изменение факторов, влияющих на осуществление страховой компанией финансовой стратегии в связи с введением закона о «СПЛИТ» и осуществлено предсказание будущей результативности осуществления страховыми компаниями своей финансовой стратегии в условиях практического внедрения Закона о "СПЛИТЕ".

Ключевые слова: финансовая стратегия; сплит; небанковский финансовый рынок; регулятор; страховая компания. 


\author{
Olena Sobolieva-Tereshchenko \\ $\mathrm{PhD}$ in Economics, Associate Professor \\ of Finance and Economics department, \\ Boris Grinchenko Kyiv University, \\ Kyiv, Ukraine \\ ORCID ID: 0000-0002-1086-1192 \\ e-mail:t8000@i.ua
}

\title{
Kateryna Bronitska
}

Master of Science Degree,

Boris Grinchenko Kyiv University,

Kyiv, Ukraine

e-mail: insurancekbron@gmail.com

\section{FINANCIAL STRATEGY OF THE INSURANCE COMPANY IN CONDITIONS OF IMPLEMENTATION OF LEGISLATIVE CHANGES IN REGULATION OF PARTICIPANTS OF THE FINANCIAL MARKET}

Abstract. The article examines the content and main problems of formation, implementation and management of the financial strategy of an insurance company, financial strategic planning. The place of the financial strategy in the overall system of financial planning and forecasting is indicated. The stages of implementation of financial strategies by insurance companies were elaborated on the basis of existing developments for other entities, the essence and sequence of implementation of each of the stages of application of financial strategy by the insurance company are revealed. The adequacy of the developed stages of the financial strategy of insurance companies to the existing exogenous and endogenous factors is analyzed and the application of the developed strategic stages is substantiated. The legislative changes regarding the regulation of the nonbanking financial market participants are analyzed and the probable results of these changes are determined. Positive and negative consequences of the introduction of amendments to the legislation regarding SPLIT were established. The change of factors influencing the process of implementation by non-bank financial market entities of its activity is revealed and its analysis is made based on existing statistics. On the basis of the analysis of the literary sources and the existing experience of the insurance companies, the influence of the implementation of the SPLIT Law on the financial strategy of the insurance company was investigated. The prospects and effectiveness of implementing measures to change the conditions of regulation of insurance companies as participants in the non-banking financial market are evaluated. The change of factors affecting the implementation of the financial strategy by the insurance company in connection with the implementation of the SPLIT law is analyzed and the future effectiveness of the implementation of its financial strategy by the insurance companies in terms of the practical implementation of the SPLIT law is made.

Keywords: financial strategy; split; non-banking financial market; regulator; insurance company.

\section{REFERENCES (TRANSLATED AND TRANSLITERATED)}

1. Aleksandrova, M. M. (2010). Theoretical foundations of the Insurance Company Financial Strategy. Visnyk Zhytomyrskoho Derzhavnoho Tekhnolohichnoho Universytetu, 2(52), 217-220 [in Ukrainian].

2. Furman, V. M., Filoniuk, O. F., Nikolenko M. P., Baranovskyi, O. I. (2008). Strategic management of an insurance company [monograph]. KNEU [in Ukrainian].

3. Osadets, S. S., Murashko, O.V., Furman, V. M. (2011). Insurance management: a textbook. Kyiv: KNEU [in Ukrainian]. Ukrainian].

4. Bilyk, M. D., Poddierohin, A.M., Babiak, N.D. (2017). Financial management. Kyiv: KNEU [in

5. Blank, I. A. (2008). Financial strategy of the enterprise. Kyiv: Nika-Tsentr [in Ukrainian].

6. Stanislavyk, Y. N. (2008). Basics of financial management. Mykolaiv: Os - 89 [in Ukrainian].

7. Lukina, Y.V. (2008). Formation and implementation of enterprise financial management strategy. Finansy Ukrainy. 3, 113 [in Ukrainian].

8. Dykan, L. V. (2008). Strategic management of financial resources of an industrial enterprise. Finansy Ukrainy, 3, 12-18 [in Ukrainian].

9. Hudz, O. I. (2017). Formation of financial strategy of the enterprise. Naukovyi visnyk Mizhnarodnoho humanitarnoho universytetu, 24, 107- 110. [in Ukrainian]. 
10. Honcharenko, O.M. (2015). Financial strategy: theoretical issues of development and implementation. Visnyk sotsialno-ekonomichnykh doslidzhen : zb. nauk. Prats, 56 (1), 35-40 [in Ukrainian].

11. Tang, T. L. P., Sutarso, T., Ansari, M. A., Lim, V. K., Teo, T. S., Arias-Galicia, F., ... \& Vlerick, P. (2018). Monetary Intelligence and Behavioral Economics: The Enron Effect-Love of money, corporate ethical values, Corruption Perceptions Index (CPI), and dishonesty across 31 geopolitical entities. Journal of Business Ethics., 148(4), 919-937 [in English].

12. Bas Y.V. (2016). Theoretical bases of formation of financial strategy of the enterprise. Nauka y ekonomika, 1 (41), 73-77 [in Ukrainian].

13. Kostyrko, L. A., Sereda, O. O. (2019). Financial potential as an object of financial regulation of development of business entities. Visnyk sotsialno-ekonomichnykh doslidzhen: zb. nauk. Prats, 69 (1), 149-157 [in Ukrainian].

14. Ramskyi, A., \& Budnichenko, I. (2018). Financial stability of a bank - factor of stability of banking system. European Scientific Journal of Economic and Financial Innovation, (2), 5-11. https://doi.org/10.32750/2018-0201. [in English]. 